\title{
Erratum to: Role of fecal Clostridium difficile load in discrepancies between toxin tests and PCR: is quantitation the next step in $C$. difficile testing?
}

\author{
J. L. Leslie • S. H. Cohen • J. V. Solnick • C. R. Polage
}

Accepted: 25 July 2012 / Published online: 4 August 2012

(C) Springer-Verlag 2012

\section{Erratum to: Eur J Clin Microbiol Infect Dis}

\section{DOI 10.1007/s10096-012-1695-6}

\begin{abstract}
All $\log ^{10}$ C. difficile DNA concentrations reported in the manuscript are incorrectly low by a factor of 10 and, thus, represent the number of $C$. difficile DNA copies $/ 100 \mathrm{uL}$ feces, not DNA copies $/ \mathrm{mL}$, as labeled. This includes the Y-axis labels for Figure 1 and the $95 \%$ sensitivity cutoff for prediction of toxin status. The appropriate quantitative cutoff to detect $95 \%$ of toxin positive samples is $\geq 5.1 \log ^{10} C$. difficile $t c d \mathrm{~B}$ DNA copies $/ \mathrm{mL}$. All other proportions, relationships and conclusions remain accurate and valid. The authors regret any confusion this error may cause.
\end{abstract}

The online version of the original article can be found at http:// dx.doi.org/10.1007/s10096-012-1695-6.

J. L. Leslie $\cdot$ C. R. Polage $(\bowtie)$

Department of Pathology and Laboratory Medicine,

University of California, Davis, School of Medicine,

Davis, CA, USA

e-mail: christopher.polage@ucdmc.ucdavis.edu

S. H. Cohen · J. V. Solnick $\cdot$ C. R. Polage

Department of Internal Medicine, Division of Infectious Diseases,

University of California, Davis, School of Medicine,

Davis, CA, USA

\section{J. V. Solnick}

Department of Medical Microbiology and Immunology,

University of California, Davis, School of Medicine,

Davis, CA, USA 